\title{
Analysis of the impact of financial crises on Ouro Scheffer's jewelry sales
}

\section{Luis Ferruz Agudo, Daniel Knebel Baggio, Gabriela Scheffer, Bruna Faccin Camargo}

\author{
Departamento de Contabilidad y Finanzas \\ Universidad de Zaragoza \\ Departamento de Administração, Ciências Contábeis, Econômicas e da Comunicação \\ Programa de Pós-Graduação em Desenvolvimento Regional \\ Universidade do Noroeste do Estado do Rio Grande do Sul \\ Programa de Pós-Graduação em Gestão Estratégica de Organizações \\ Universidad Regional Integrada \\ Administradora de la empresa Ouro Scheffer \\ Departamento de Contabilidad \\ Universidad Franciscana
}

This article studies financial crises and their impact on the main types of financial investment. Specifically, the objective of this study is to analyze the impact that financial crises generated in purchase of jewelry at Ouro Scheffer. It was therefore necessary to first revise the concept of main types of investment in variable income and fixed income, as well as a history of gold, and to analyze the main financial crises. Applied and quantitative research was then carried out with an analysis of three temporal series: gold, Ibovespa and Ouro Scheffer's jewelry sales revenue. The results found that the main financial crises of 1999 and 2008 had an impact on the jewelry sales temporal series. It was also possible to determine that these crises generated an impact on the gold and Ibovespa temporal series.

Keywords: investment, gold, financial crises

\section{Análisis del impacto de las crisis financieras en las ventas de joyas de la empresa Ouro Scheffer}

Este artículo aborda las crisis financieras y los principales tipos de inversiones financieras, teniendo como objetivo general analizar el impacto que las crisis financieras causan en la compra de joyas en la empresa Ouro Scheffer. Para ello, se hizo necesario revisar los conceptos de los principales tipos de inversiones en renta variable y renta fija, histórico del oro y mapear las principales crisis financieras. Para alcanzar el objetivo de este estudio, se realizó una investigación de carácter aplicada, cuantitativa, con análisis de tres series temporales: Ouro, Ibovespa y Recetas de ventas de joyas de la empresa Ouro Scheffer. Los resultados encontrados demuestran que las principales crisis financieras de 1999 y 2008 tuvieron impacto en la serie temporal de ventas de joyas. También fue posible conocer el impacto que las crisis causaron en las series temporales Ouro e Ibovespa.

Palabras clave: inversiones, oro, crisis financieras. 


\section{Análise do impacto das crises financeiras nas vendas de joias da empresa Ouro Scheffer}

Este artigo aborda sobre as crises financeiras e o principal tipo de investimento financeiro. O objetivo geral deste trabalho é analisar o impacto que as crises financeiras causam na compra de joias na empresa Ouro Scheffer. Com esse intuito, foi necessário verificar o conceito de principais tipos de investimento em renda variável e renda fixa, histórico de ouro e analisar as principais crises financeiras. Para atingir o objetivo deste estudo, foi realizada uma pesquisa aplicada e quantitativa com a análise de três séries temporais: Ouro, Ibovespa e receita de vendas de jóias da empresa Ouro Scheffer. Os resultados encontrados demonstram que as principais crises financeiras de 1999 e 2008 tiveram impacto nas séries temporais de vendas de joias. Também foi possível conhecer o impacto que as crises causaram nas séries temporais ouro e Ibovespa.

Palavras chave: investimentos, ouro, crises financeiras.

\section{Introduction}

People count on multiple investment options, such as real estate investments, opening new businesses or investments in the financial market. When executing an investment, in addition to liquidity, the combination of risk and return should be taken into consideration, that is, that the greater the expected return, the greater the acceptance and exposure to risk by the investor (Bodie, Kane $\&$ Marcus, 2000).

A distinction can be made between fixed and variable income investments. The financial products of fixed income attract investors, due to their low risk and virtually guaranteed returns, and also because at the time of application, it is possible to know in advance the returns that will be received at the end of the application, in the case of a pre-fixed investment (Hissa, 2012). There are several types of fixed income investments, such as savings accounts, certificates of deposit (CDB), public bonds, bills of exchange and some investment funds. Savings accounts are the simplest and most traditional fixed income investment among Brazilians, due to its immediate liquidity, low risk and exemption of income tax (Cerbasi, 2008). Therefore, as explained by Cerbasi (2008), savings accounts are one of the most popular and conservative investments, especially among people with few options for investment.

The risks of investment in variable incomes are greater, particularly when examined through a macroeconomic perspective, according to which these investments are exposed to risks of both national and international scope. This means that because companies and countries are interconnected, a change in the United States may negatively impact Brazil and the investments of the Brazilian Stock Exchange, in addition to those of its American counterpart. Variable income investments garner a higher degree of risk in crisis situations and investors direct their savings towards safer investments, such as those of fixed income and gold. According to Cerbasi (2008), gold is a safe haven for investors during economic crises, especially those that have a strong impact on the financial system, although it is not, strictly speaking, a fixed income investment.

Despite not being a traditional form of investment, purchasing jewelry can be considered an alternative to those who wish to invest in gold. Even though there are differences between the price of gold and that of jewelry, in crisis situations, neither gold nor jewelry tend to lose value, thus constituting a secure investment. 
In this context, the overall objective of this article is to analyze the impact that financial crises generate in Ouro Scheffer's jewelry sales, through a brief literature review on gold as an alternative investment, a presentation of the history of gold, Ibovespa and Ouro Scheffer's jewelry sales, and, finally, a review of the main Western economic and financial crises. Additionally, this case study analyzes three temporal series, between 1997 and 2013: Ibovespa, gold prices and Ouro Scheffer's jewelry sales revenues. The data used for these three temporal series was gathered from BM\&F Bovespa's and Banco Central do Brasil - BACEN's financial websites, gold.org and Ouro Scheffer reports. The data was analyzed by using Microsoft Excel. Finally, in addition to the graphical analysis, an analysis of Pearson's correlation coefficient was executed, with the purpose of verifying the degree of correlation between the three variables.

\section{Theoretical framework}

\subsection{Gold Production in Brazil}

In Brazil, at the end of the seventeenth century, sugar production went through a major crisis, due to the large amount of new sugar mills in the French, Dutch and English colonies in Central America. Portuguese colonies paid taxes to Portugal, which were then its main source of revenue. The Portuguese Crown therefore began to encourage its workers and other inhabitants to explore the as-yet-unknown land in search of precious stones and gold (Valente, 2012; Baer, 2002; Roncari, 2002). The eventual discovery of the stone in Brazil generated a true "gold rush»: Portuguese and even Brazilians from all over began to migrate to the auriferous regions in search of easy and fast enrichment (Valente, 2012; Baer, 2002; Roncari, 2002). However, disappointment soon took hold, as the exploitation of the newly discovered gold mines depended on high investments such as the acquisition of African slaves, equipment and land. This meant that only big merchants and rural owners were able to invest in the profitable gold market (Valente, 2012; Roncari, 2002).

Whoever found gold in its colonies had to tribute a fifth of it to the Portuguese Crown, which profited from levying taxes and duties. These taxes were charged in casthouses, where gold was melted and then transformed into bars. One fifth $(20 \%)$ of the bars produced was set apart, to send to Portugal (Baer, 2002; Roncari, 2002). The Southeast region of Brazil developed highly with the exploitation of gold, while its Northeast region began to enter into crisis. Given this situation, the Portuguese Crown decided to transfer the Brazilian colony's capital from Salvador da Bahia to Rio de Janeiro, so that it stayed close to the new center of economic development. This would spur large growth of the population and the establishment of an internal market, because the colony's products were no longer solely for export, as was the case with sugar in the Northeast. This, in turn, created the necessity for an internal production of food that could meet the needs of new residents (Valente, 2012; Baer, 2002).

\subsection{The Gold Market}

The first step for investors who wish to invest in gold is to choose how they want to go about doing it, since there are direct and indirect ways to bet on the gold market as an investment. The most advisable and common ways are futures contracts, the physical purchase of gold in bars and investment funds (Gallagher, 2008; Newlands Junior, 2011; Roberts, 2000).

Before investing in futures contracts at BM\&F Bovespa, it is essential to seek a company affiliated to it, such as a brokerage firm or bank, to draft the contract and 
allow for the negotiation. In this type of negotiation, investing in gold is equivalent to investing in variable income (Gallagher, 2008; Newlands Junior, 2011). According to Roberts (2000), in order to obtain greater liquidity in the buying and selling of contracts, this system allows for the negotiation of fractional contracts of 0.225 grams to up to 10 grams or, in full contracts, 250 grams. Custody is upheld by the broker, and only a brokerage rate is paid for the negotiation of the investment. This method is recommended for investors who intend to invest in the short and medium term, based on speculation of currency value.

In order to buy gold in bars, finding a company or bank that sells the product is necessary. This part of the process is slightly bureaucratic, because it requires a registration of proof of income for purchases above USD\$ 10,000.00. Finding a bank that can store the gold in bars, i.e., a custodian bank, for which a monthly fee on the amount of financial volume generated is paid, which can vary from $0.07 \%$ to $0.15 \%$ (Newlands Junior, 2011; Roberts, 2000), is also necessary.

Gallagher (2008) says that for the purchase of physical gold, yet another option is to contact a distributor for the negotiation and to custody the gold at home. In this type of investment, the risk of losing the asset is greater, because the gold is not kept by the company responsible for the product, which has insurance against theft and other security measures required for financial assets in custody. One of the disadvantages of this type of investment is the low liquidity at the time of sale, because it is more difficult to find someone willing to pay market price.

Regarding investment funds, Paz and Bastos (2012) report that they are one of the most accessible options in the market, given that this method eliminates bureaucratic concerns with buying gold in bars as well as concerns regarding oscillations of the future market, because it outsources the management of this asset to a professional administrator. Investment funds may be both active, buying and selling gold with an increased profitability goal, which varies according to market timing; or passive, buying gold and simply withstanding variations in price.

Finally, according to a detailed report from the Ministry of Finance (2003), the purchase of jewelry is another option for investing in gold. In this case, consumers buy gold jewelry and mainly pay attention to profitability.

\subsection{Economic and Financial Crises}

Bêrni (2000) defines a financial crisis as the occurrence of sudden situations in which financial assets or financial institutions along with non-financial corporations lose confidence in the currency and the banking system, which in turn leads to a sudden devaluation and higher vulnerability of the economies affected by the financial weakness. These crises can be associated to factors of unbalance and the stability of a country's financial system. These crises are characterized by the collapse of the stock market, the bursting of a financial bubble or even speculative attacks on countries' currencies, factors that, combined, determine the vulnerability of a country facing the crisis (Bêrni, 2000). According to Cooper (2009) and Aglietta (2004), no consensus exists among economists on how to avoid financial crises, which is probably why they continue to occur all throughout the world and with some regularity, as a result of the normal functioning of a country's economy.

The world has faced global crises since the beginning of the capitalist system. One of the largest and most notorious crises was the 1929 crisis, which began with the collapse of the New York Stock Exchange, resulting 
in huge damage to the world economy and global financial market as a whole (Cooper, 2009). The crisis of the Brazilian real in 1999 and the worldwide crisis of 2008 will be detailed for better understanding, since they will be used as the basis for the analysis of the gold, Ibovespa and Ouro Scheffer jewelry sales temporal series.

In the first case, the low exchange rates in 1999 and the crisis of the real are associated with structural problems of the plan implemented in Brazil to fight inflation. The overvaluation of the real against the euro, the yen, the US dollar and other hard currencies generated negative consequences, such as the decline of domestic industry and the increase of trade deficits (Modenesi, 2005). Modenesi (2005) also reminds us that, in the short term, companies that acquired loans abroad had more damages, because the value to be paid back grew rapidly in reais. The increased tension between Brazil and Argentina was another consequence, since Argentina implemented the circulation of the US dollar as official currency in its domestic economy, in addition to the fixed parity. Because of the exchange devaluation, Brazil generated a huge commercial surplus with Argentina, aggravating, in the period between 1999 and 2000, the Argentina's external accounts situation. Dezordi (2010) states, however, that this crisis also generated several positive consequences. Among them, the author mentions the end of the flow of dollars that contributed to the overvaluation of the real, the control of public debt and a reduction of the deficit in the balance of payments, showing that, in the long term, unlike other crises, this one was actually positive for the Brazilian economy.

In the second case, while the critical point of the international financial crisis in 2008 was the collapse of Lehman Brothers that year, the onset of the crisis actually unfolded throughout 2007, with the infa- mous American subprimes and the deterioration of the mortgage market (Além, 2010). Beyond (2010) says that in 2008 the international financial crisis was considered one of the worst crises since the Great Depression of 1929 . Its consequences were so disastrous that, between 2007 and 2008, the very World Federation of Stock Exchanges was devalued in the stock market by US $\$ 29.5$ trillion. Because of the 2008 crisis, some financial institutions collapsed due to lack of liquidity caused by their debtors' inability to pay back their loans. The immediate reaction by the banks that provided the loans was to increase interest rates, which ended up exposing the loans as unfeasible in the first place (Posner et al., 2012).

Bruner (2010) clarifies that the sale of commercial dollars in Brazil had been following a steady course since October 2002, when it was valued at $3.95 \mathrm{R} \$$ / USD\$ and, in August 2008, reached a value of 1.55 R\$/USD\$. Due to losses by international investors, coupled with the fear of a worldwide recession, there was a large output of dollars from the Brazilian market. The Brazilian real was therefore heavily devalued, variating between August and October 2008 by a percentage of $35 \%$. According to the author, the first signs of crisis in 2008, initially seen in foreign exchange operations, were layoffs, company restructuring, cuts in international investments and procedure revisions in the risk departments of commercial banks.

\section{Method}

\subsection{Research Design}

This study is causal and aims to verify the impact that financial crises cause in Ouro Scheffer's purchase of jewelry. The analysis will be quantitative, since the information and data collected were converted into numbers. 
Regarding the temporal cut-off, this study is longitudinal, allowing for the evaluation and monitoring of changes over a period of time, and not just the analysis of a discrete moment, as with cross-section cut-off. To understand the impact that financial crises have on Ouro Scheffer's purchase of jewelry, this study also qualifies as a case study, due to relying heavily on data regarding the monthly sales of jewelry in Ouro Scheffer.

Three temporal series were analyzed: Ibovespa, gold and Ouro Scheffer's jewelry sales revenues. The period of analysis is between January 1997 and August 2013, totaling 200 cases by variable and 600 cases in general. Monthly quotations from Ibovespa (in points) and gold (in dollars) along with the last quotation from each month were employed. Regarding the jewelry sales, the data employed was Ouro Scheffer's jewelry sales. The population of study is considered to be represented by the entire historic listing of the three temporal series analyzed. Furthermore, this time period was deemed relevant for the study because all throughout it there were important crises, which are observed in the data analysis. In addition, this period coincides with the moment Ouro Sheffer's data became available, and is posterior to the 1994 creation of the Real Plan.

In this study, a secondary data collection method was used, based on publications and computerized databases. The data was obtained from the BM\&FBOVESPA database (http://www.bmfbovespa. com.br), Banco Central do Brasil (http://www. bcb.gov.br) and gold.org (http://www.gold.org/). On these sites, it was possible to obtain quotations from Ibovespa and gold. Internal reports and Ouro Scheffer's jewelry sale records were also used, through which monthly sales values of jewelry were obtained.
The analysis and treatment of data occurred as follows. Once information was gathered for the three temporal series on BM\&FBOVESPA's and Banco Central do Brasil's financial websites and on gold.org, along with from Ouro Scheffer reports, the information was duly organized for the generation of results and analysis using Microsoft Excel. The first analysis was the descriptive tabulation of the data into historical charts. For each of the three series, the moments that the two main global financial crises of the past two decades occurred were indicated, and their impact on the temporal series was analyzed. The next step was the comparative graphic analysis (i) between the Ibovespa and gold series, (ii) between the Ibovespa and jewelry sales series, (iii) between the gold and jewelry sales series and, finally, (iv) a graphical analysis between all three series. A Pearson's correlation analysis was also executed, in order to verify the degree of correlation among these three variables. To determine whether two or more variables are associated, there must be covariance between them. Pearson's correlation coefficient is used to identify this association. The higher the coefficient, the more likely that there be high covariance and a strong relationship between the analyzed variables; likewise, the lower the coefficient, the more likely that there be low covariance and a weak relationship between the variables (Hair Jr., Babin, Money \& Samouel, et al. 2003). The table below shows which coefficient values indicate which association force.

Table 1. Values of correlation coefficient

\begin{tabular}{|c|c|}
\hline Coefficient correlation & Association force \\
\hline $0.91-1.00$ & Very strong \\
$0.71-0.90$ & High \\
$0.41-0.70$ & Moderate \\
$0.21-0.40$ & Small but defined \\
$0.01-0.20$ & Little, almost unnoticeable \\
\hline
\end{tabular}

Source: adapted from Hair Jr. et al. (2003). 
According to Hair Jr. et al. (2003), in order to be able to use Pearson's correlation coefficient, several assumptions about the data must be made. First, the variables are assumed to have been measured using metric measurements. Another assumption is that the variables are nominal or ordinal, and a third and final one is that the variables were measured in a normally distributed population.

Since the analysis of the jewelry sales temporal series was included, in order to determine whether the financial crises generated in it any impact, the analysis model of intervention and estimates proposed by Box and Jenkins was used in order to elucidate its trend. The Box and Jenkins methodology refers to the systematic method of identification, regulation, control and auto-regressive integrated use of moving average, or, simply put, ARIMA models. The use of ARIMA models is a powerful solution for many problems of prediction and can provide very precise predictions of temporal series (Box, Jenkins \& Reinsel, 2008). The econometric software Eviews 5.0 was used to transform the initial jewelry sales temporal series graph, which now displayed a trend.

With this new transformed temporal series, it was possible to create a lag dependence function (LDF) graph and a partial lag dependence function (PLDF), which allowed to check for the presence of autocorrelation in the data series, i.e., to analyze the existence of significant dependence among data of the jewelry sales series. Lag dependence is detectable in slight lag falls in the functions graphs.

Once the existence of a trend and lag dependence in the jewelry sales series were verified, another modification was executed with the insertion of autoregressive components and/or moving averages. Due to the insertion of these components, it was possible to gen- erate new LDF and PLDF charts and then execute an intervention analysis. It should be emphasized that, in theory, the new LDF and PLDF graphs should present a rapid fall, thus demonstrating the absence of lag dependence.

After adjusting the series and completing the lag dependence tests, it was possible to carry out the construction of the analysis model, that is, the estimation of the ARIMA model parameters $(p, d, q)$ and the indication of the moments of intervention in the temporal series. The best model is the one that exhibits the best Akaike information criterion (AIC). After detecting the moments of intervention, it was possible to analyze what occurred at these moments in the temporal series, or also in earlier moments. These moments of intervention are expected to have occurred shortly after the crises periods of 1999 and 2008. In case they occurred before the crises or for longer periods of time after the crises, it is assumed that there is a relationship between the financial worldwide crises and Ouro Scheffer's jewelry sales.

\section{Results and Discussion}

\subsection{Ibovespa and Crises}

Figure 1 shows the Ibovespa graph in blue and the arrows indicate the 1999 Brazilian-Mercosur crisis and the 2008 global crisis.

The two crises occurred during the period of analysis, in 1999 and 2008. The 2008 crisis caused a negative impact in Ibovespa, since its actions suffered a considerable depreciation, as is observed in the period between January 2008 and January 2009. The 1999 crisis, however, did not have a significant impact on Ibovespa, perhaps because during this period Bovespa operated at a very low level, with values of 
around $\mathrm{R} \$ 1,000,000.00$. Ibovespa dropped from 59490,40 points in January 2008 to 39300,79 points in January 2009, as shown in Figure 1.

\subsection{Gold and Crises}

Figure 2 shows the graph of gold quotations in blue and the arrows indicate the 1999 and 2008 crises.

By analyzing Figure 2 above, a positive impact on gold can be observed in 2008, due to an increase in the value of the gram, moving from $\mathrm{R} \$ 50.62$ in January 2008 to $\mathrm{R} \$ 63.50$ in January 2009. Likewise, in January 1999 , the gram of gold also increased significantly, from $\mathrm{R} \$ 11.17$ to $\mathrm{R} \$ 16.91$ in January 2000. Moreover, gold has been appreciating over the years: in January 1997, the gram of gold was worth around $\mathrm{R} \$ 11.95$, whereas in August 2013 it reached R\$97.01. During this period, the value of gold fluctuated; however, in 2012, it leaped from $\mathrm{R} \$ 74.14$ in January 2011 to $\mathrm{R} \$ 96.37$ in January 2012. And it did not stop there, reaching its highest peak in October 2012, when the value of the gram almost reached $\mathrm{R} \$ 116.00$.

\subsection{Sales and Crises}

Figure 3 shows Ouro Scheffer's jewelry sales graph in blue, while the arrows indicate the moment when the 1999 and 2008 crises occurred.

Figure 1. Ibovespa and crises

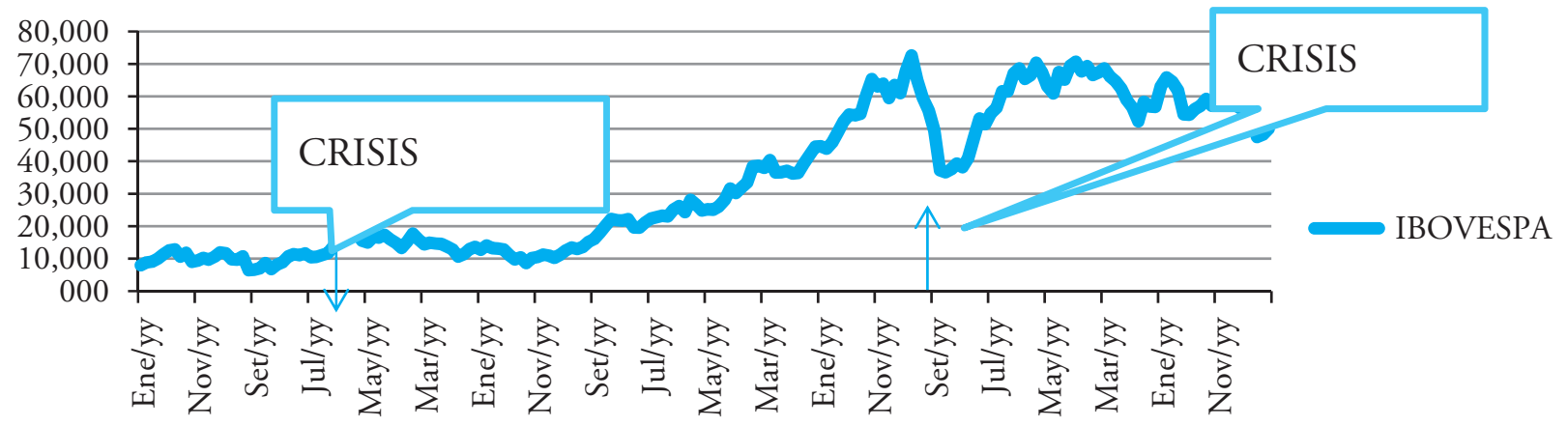

Elaborated by the authors (2013).

Figure 2. Gold and Crises

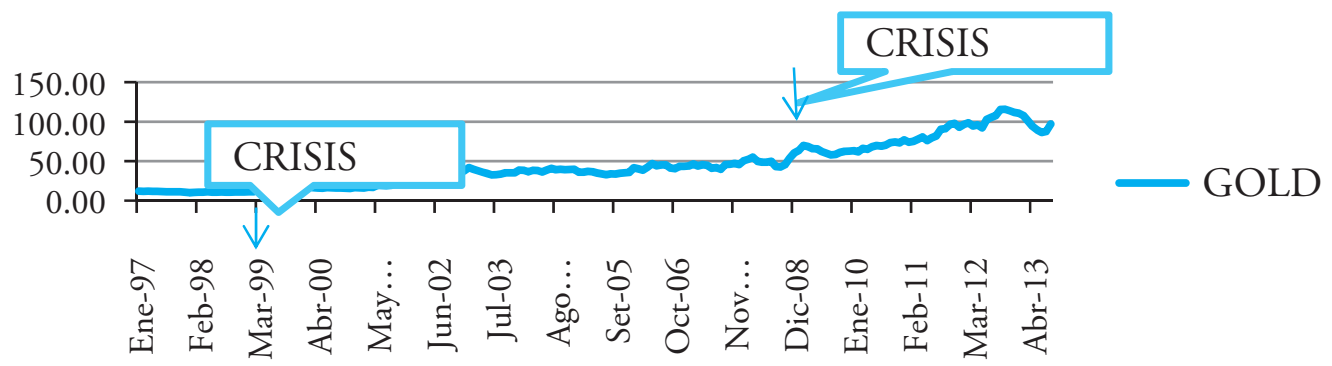

Elaborated by the authors (2013). 
In the graph above, an increase in sales to Ouro Scheffer in 1999 can be observed, from $\mathrm{R} \$ 9,380.96$ in January 1999 to $R \$ 31,643.69$ in December of the same year. In 2008, in accordance with the gold peak from the previous graph, sales also presented a significant increase, rising from $\mathrm{R} \$ 63,275.00$ in January 2008 to $R \$ 117,663.00$ in December of the same year.

\subsection{Ibovespa, Gold and Crises}

Figure 4 shows the Ibovespa graph in blue and the gold graph in red, while, once again, the arrows indicate the 1999 Brazilian and 2008 global crises.

As it can be seen from the previous charts, Ibovespa dropped significantly between 2008 and
2009, from 59490,40 points in January 2008 to 39300,79 points in January 2009. In the same period, the gram of gold increased considerably, from $\mathrm{R} \$ 50.62$ in January 2008 to $\mathrm{R} \$ 63.50$ in January 2009. Figure 4 shows the moment when the Ibovespa index (blue line) dropped and the value of gold (red line) increased during 1999 and 2008. In 2012, following a large increase in the price of gold throughout the previous year, reaching R \$ 41.00 per gram, Ibovespa remained unstable, ranging from 68.000 to 55.000 points.

\subsection{Ibovespa, Sales and Crises}

Figure 5 shows the Ibovespa graph in blue and the sales graph in red, while the arrows indicate the 1999 Brazilian-Mercosur and 2008 global crises.

Figure 3. Sales and Crises

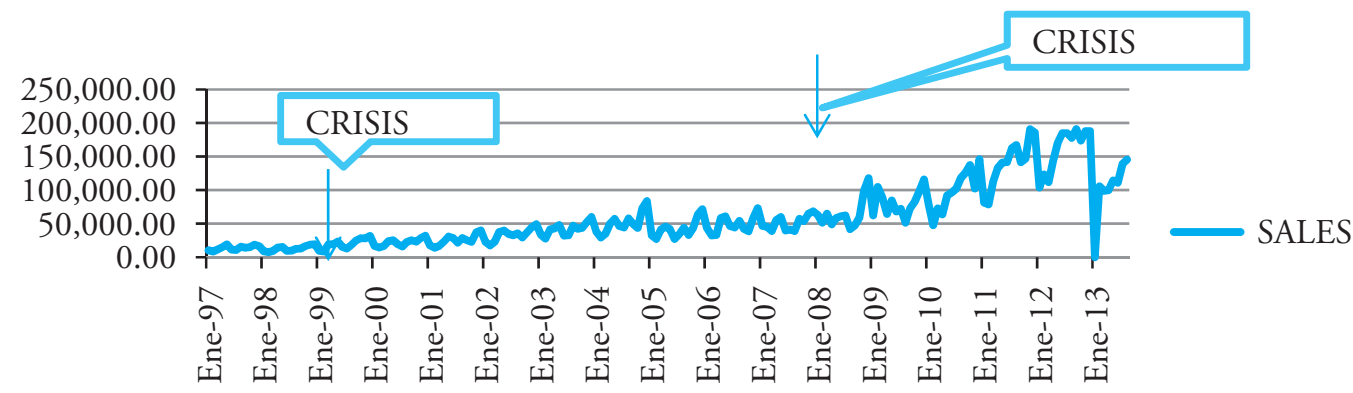

Elaborated by the authors (2013).

Figure 4. Ibovespa, Gold and Crises

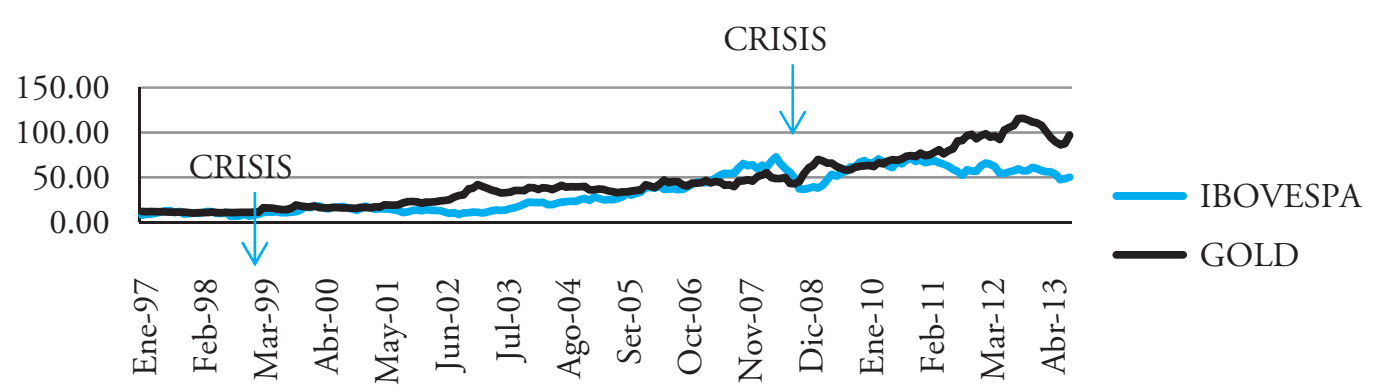

Elaborated by the authors (2013). 
It can be gathered from the previous graphs that sales increased in both 1999 and 2008, while Ibovespa significantly decrease in 2008. Figure 5's red line indicates that sales increased from $\mathrm{R} \$ 41,836.20$ in August 2008 to $\mathrm{R} \$ 117,663.00$ in December 2008, while the Ibovespa's blue line went from 55,680.41 in August 2008 to $37,550.31$ points in December of the same year.

\subsection{Gold, Sales and Crises}

Figure 6 shows the gold graph in blue and the sales graph in red, the arrows indicating both of the crises under analysis.

The graph shows that both gold and sales grew significantly between 1997 and 2013. In 1999, when the Brazilian crisis occurred, gold dropped slightly, from $\mathrm{R} \$ 11.95$ in January 1997 to $\mathrm{R} \$ 10.41$ in January 1998, oscillating between these quotations for over a year. Sales also dropped, ranging from $\mathrm{R} \$ 11.95$ to R\$ 10.00 between January 1997 and January 1999. While jewelry sales increased from January 2007 to January 2008, as shown in Figure 6, sales increased by $\mathrm{R} \$ 20,000.00$ from one year to the next, gradually maintaining this increase up until 2013.

\subsection{Ibovespa, Gold, Sales and Crises}

Figure 7 shows the Ibovespa graph in blue, the gold graph in red and the sales graph in black, while the arrows indicate the 1999 Brazilian-Mercosur and the 2008 global crises.

Figure 5. Ibovespa, Sales and Crises

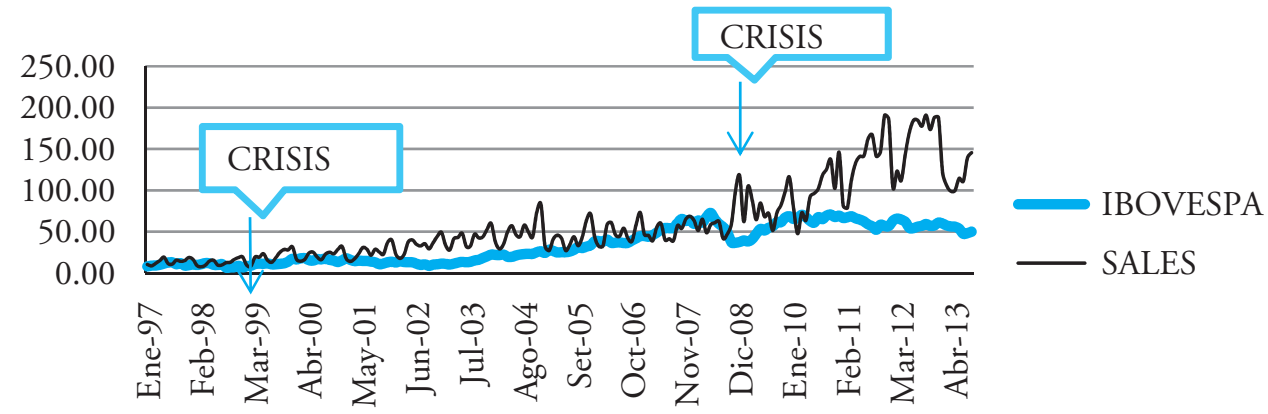

Elaborated by the authors (2013).

Figure 6. Gold, Sales and crises

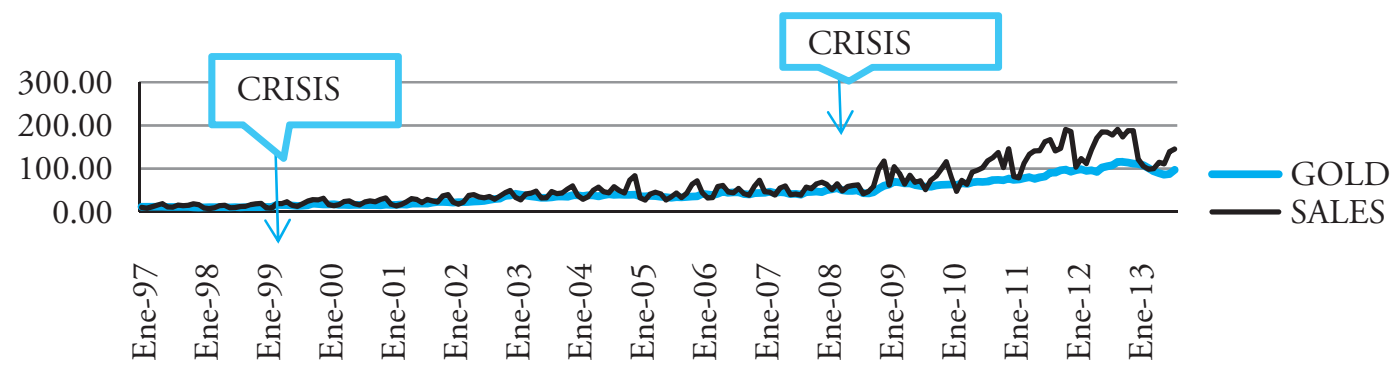

Elaborated by the authors (2013). 
Figure 7. Ibovespa, Gold, Sales and Crisis

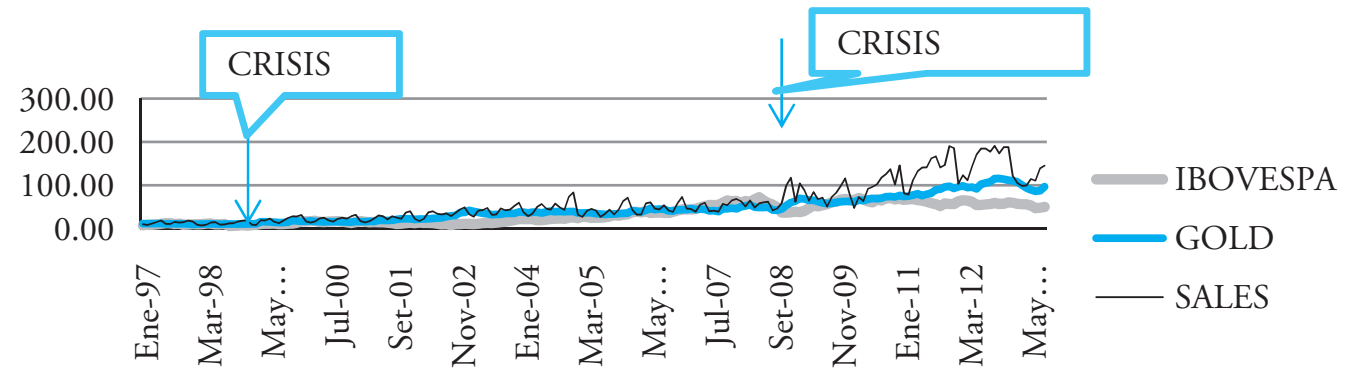

Elaborated by the authors (2013).

Figure 7 shows that sales, throughout 2008, in relation to Ibovespa and gold, presented higher oscillation, the values varying from month to month as follows: $\mathrm{R} \$ 63,275.00$ in January; $\mathrm{R} \$ 51,430.00$ in February; $\mathrm{R} \$ 65,029.80$ in March; $\mathrm{R} \$ 48,725.00$ in April; $\mathrm{R} \$ 58,404.00$ in May; $\mathrm{R} \$ 60,837.50$ in June; $\mathrm{R} \$ 62,312.50$ in July; $\mathrm{R} \$ 41,836.20$ in August; $\mathrm{R} \$ 46,959.00$ in September; $\mathrm{R} \$ 58,994.00$ in October; R\$99,548.00 in November; and R\$117,663.00 in December 2008. Ibovespa and gold fluctuated during this same period, as can be seen in Figure 7. Gold's red line rises, showing an appreciation of the gram of gold, while Ibovespa's blue line descends, indicating a drop in stock value.

Correlation was evaluated among all three variables (Ibovespa, gold and jewelry sales), producing the following coefficients: 0.735461 between Ibovespa and jewelry sales; 0.829979 between Ibovespa and gold; and 0.906637 between gold and jewelry sales. The relationship between gold and jewelry sales displayed the highest correlation $(\mathrm{r}=0.906637)$, indicating a very strong relationship between these variables. The relationships between Ibovespa and gold $(r=0.829979)$ and Ibovespa and jewelry sales $(r=0.735461)$ also showed correlation, which indicates association in both couples.

\subsection{Analysis of Temporal Series}

In figure 8 , a graph of the original jewelry sales series is presented.

Figure 8. Original Jewelry Sales Series

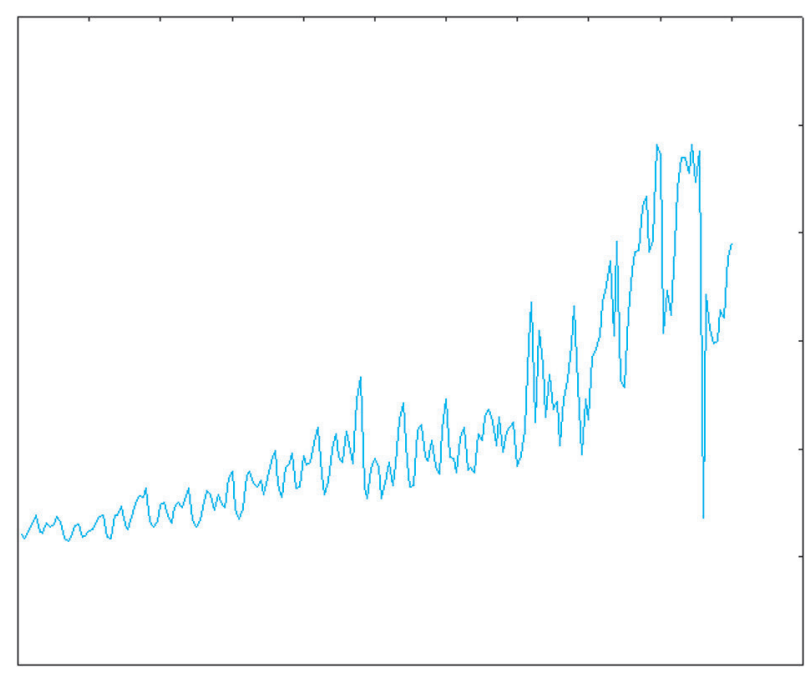

Elaborated by the authors (2013).

As previously explained, the original series was transformed, eliminating its trend so that it could be analyzed. This result that can be seen in figure 9, (sales: $\mathrm{L}$ in blue and sales: trm in red). 
Figure 9. Modified Jewelry Sales Series

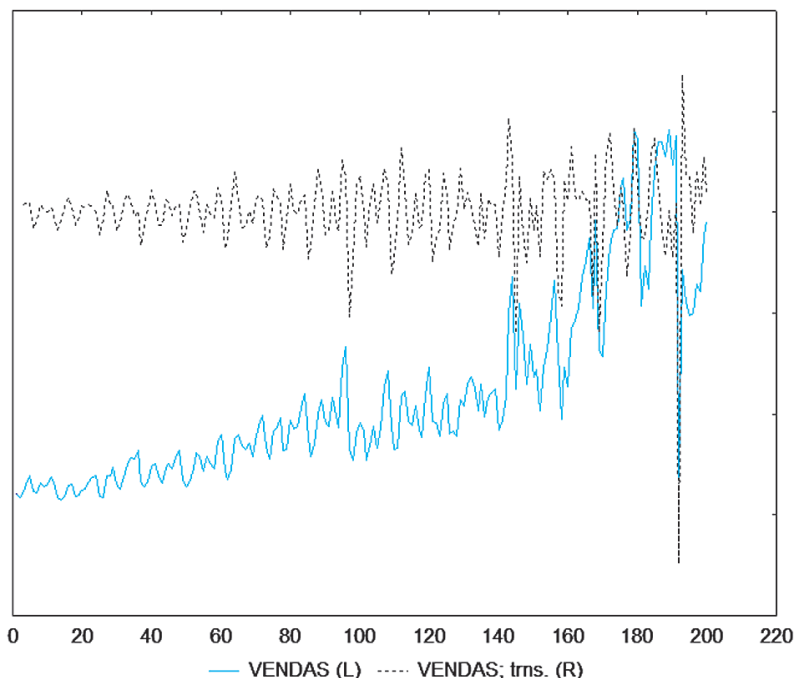

Elaborated by the authors (2013).

The following two figures show, respectively, the lag dependence function (LDF) and the partial lag dependence function (PLDF) graphs for the original series, in which, within the dotted red lines, a steady drop can be observed in the lags.

Figure 10. Original Series LDF

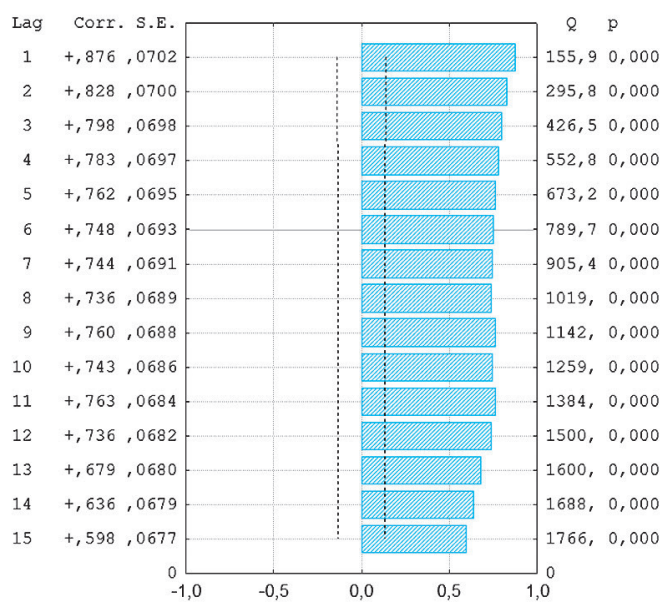

Conf. Limit

Elaborated by authors (2013)
Figure 11. Original Series PLDF

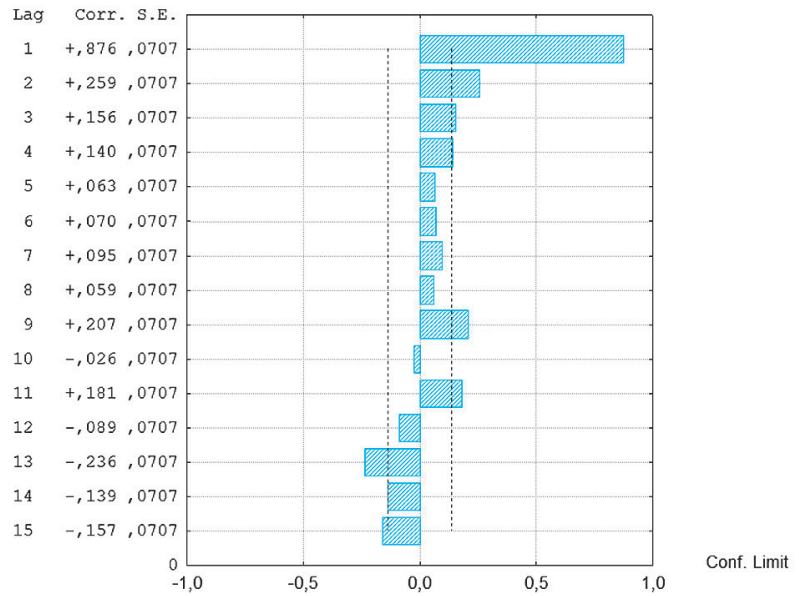

Elaborated by the authors (2013).

The following two figures, on the other hand, show, respectively, the lag dependence function graph and the partial lag dependence function graph for the modified series, in which a fast drop in modified series' lags can be observed within the area established by the dotted red lines.

\section{Figure 12. Modified Series LDF}

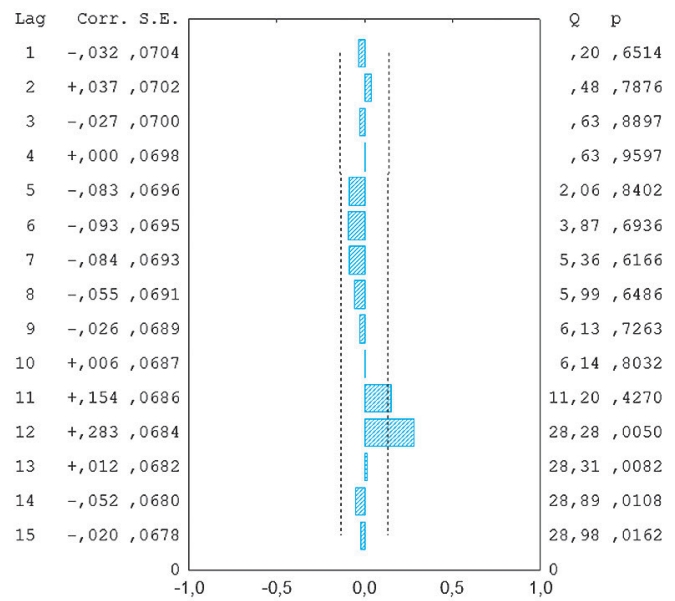

Conf. Limit

Elaborated by the authors (2013). 
Figure 13. Modified Series PLDF

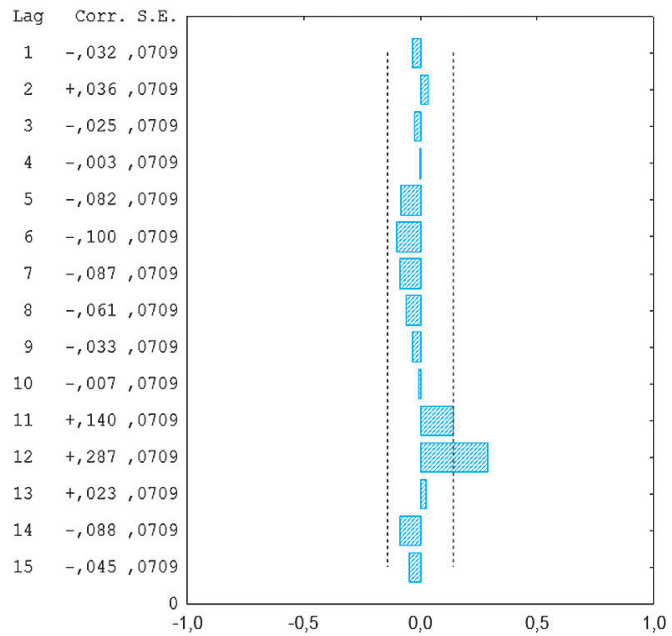

Elaborated by the authors (2013).

The following table identifies appropriate models, along with their respective parameters, AICs, types of intervention and instants of occurrence.
Having analyzed the temporal series' lag dependence function in figure 12 and the partial lag dependence function in figure 13, it is evident that the ARIMA model $(2,1,0)$, with an abrupt temporary intervention, which occurred in the 180 datum, is the one that presented the best results. The 180 datum corresponds to November 2011, as verified in the temporal series graphs, while the major financial crises occurred in 1999 and 2008, which indicates that these were not significant in the analyzed series. In 2011, Ouro Scheffer, probably because the price of gold was favorable for sale, expanded its area of coverage and provided more services to industries and jewelers, in consequence expanding its sales.

As we have just mentioned, the 180 datum occurred in 2011 while the studied crises occurred in 1999 and 2008, which shows that sales did not have any association with the financial crises that occurred during these periods. The intervention can therefore be understood as simply a result of Ouro Scheffer's expansion in 2011.

Table 2. Models Found for Jewelry Sales Series

\begin{tabular}{|c|c|c|c|c|c|}
\hline Models & Parameters & p-value & AIC & Intervention & $\begin{array}{c}\text { Instant } \\
\text { of Intervention }\end{array}$ \\
\hline $\operatorname{ARIMA}(1,2,1)$ & $\begin{array}{c}\mathrm{p}(1)=-0.5324 \\
\mathrm{q}(1)=0.98753 \\
\mathrm{Om}(1)=-0.546 \mathrm{E} 2\end{array}$ & $\begin{array}{l}0.0000 \\
0.0000 \\
0.0064\end{array}$ & 20.068 & $\begin{array}{l}\text { Abrupt } \\
\text { temporary }\end{array}$ & 180 \\
\hline $\operatorname{ARIMA}(2,1,0)$ & $\begin{array}{c}\mathrm{p}(1)=0.35497 \\
\mathrm{q}(2)=0.83715 \\
\operatorname{Om}(1)=37595.0 \\
\operatorname{Del}(1)=-5180\end{array}$ & $\begin{array}{l}0.0001 \\
0.0000 \\
0.0078 \\
0.0056\end{array}$ & 19.69 & $\begin{array}{c}\text { Abrupt } \\
\text { Temporary }\end{array}$ & 180 \\
\hline $\operatorname{ARIMA}(1,2,1)$ & $\begin{array}{c}\mathrm{p}(1)=-0.5326 \\
\mathrm{q}(1)=0.98740 \\
\mathrm{Om}(1)=-546 \mathrm{E} 2 \\
\operatorname{Del}(1)=0.98648\end{array}$ & $\begin{array}{l}0.0000 \\
0.0000 \\
0.0079 \\
0.0000\end{array}$ & 20.08 & $\begin{array}{c}\text { Abrupt } \\
\text { Temporary }\end{array}$ & 180 \\
\hline
\end{tabular}

Elaborated by the authors (2013). 


\section{Final considerations}

With a wide variety of options available to people who wish to invest their capital, be it by opening new businesses, making real estate investments, participating in the financial market or even purchasing gold and jewelry, and also taking into consideration the impact that financial crises have on these investments, the study of the impact of these crises in the purchase of jewelry became highly relevant. Because of this, the present study aimed to analyze the impact of financial crises on Ouro Scheffer's jewelry sales.

Through the analysis of the results here presented, the underlying assumption of this study was verified, i.e., that the gold, Ibovespa and jewelry sales temporal series could be explained, in part, by the background information analyzed and presented in this study. To carry it out, the Box and Jenkins intervention methodology was used. Regarding the jewelry sales temporal series, for which an intervention point was indicated at the 180 datum (which corresponds to November 2011), it was found that this datum had no impact in relation to the financial crises studied in this article, given that it did not occur in dates close to the 1999 and 2008 financial crises. Therefore, it can be concluded that the intervention at the 180 datum corresponding to November 2011 for the jewelry sales variable had no direct relationship with the 1999 and 2008 financial crises, but, rather, with some event specific to Ouro Scheffer. Despite this, the graphs showed that Ouro Scheffer's jewelry sales have had steady growth, along with a high degree of correlation with the gold dependent variable.

For the two gold and Ibovespa temporal series, the impact of the financial crises was analyzed using the quotations graphs. They demonstrated that, after the 2008 global crisis, the Ibovespa temporal series dropped sharply and the gold temporal series presented strong appreciation. It was therefore determined that these two temporal series were impacted by the 2008 crisis.

Regarding its theoretical contributions, this study showed the importance of the main types of investment, as well as the risk and solvency that each of them generates. It also presented a history of gold, emphasizing jewelry and financial crises, detailing the ones relevant to this study, the 1999 Brazilian crisis and the 2008 global crisis. This study is therefore a contribution to the theory, as there are at present no studies analyzing the impact that financial crises cause on jewelry sales in Brazil. Another important conclusion is that, regardless of financial crises, investments always have specific risks and returns, with fixed income investments presenting lower risks and variable income investments, such as stocks, typically presenting higher risk.

\section{References}

Aglietta, M. (2004). Macroeconomia financeira: crises financeira e regulação monetária. Vol. 2. São Paulo: Loyola.

Além, A. C. D. (2010). Macroeconomia: teoria e prática no Brasil. São Paulo: Elsevier.

Baer, W. (2002). A economia brasileira. Edite Sciulli (trans.). 2. ed. São Paulo: Nobel.

Banco Central do Brasil (2013). Pepitas de ouro: curiosidades sobre o ouro. Available at: http://www.bcb.gov. br/?curiouro

Bêrni, D. A. (2000). Reflexos da reestruturação produtiva mundial sobre a economia do Rio Grande do Sul. Porto Alegre: Edipucrs.

BM\&FBOVESPA. (2013). Indice Bovespa - Bovespa. Available at http://www.bmfbovespa.com.br/indices/Resumo Indice.aspx?Indice=Ibovespa $\&$ Idioma $=$ pt - br

Contabilidad y Negocios (13) 26, 2018 / ISSN 1992-1896 
BM\&FBOVESPA, C. (2013). Indice Bovespa - Ibovespa. Available at http://www.bmfbovespa.com.br/indices/ ResumoCarteiraTeorica.aspx? Indice=Ibovespa \&idioma $=$ pt-br

Bodie, Z., Kane, A., \& Marcus, A. J. (2000). Fundamentos de investimentos. Robert Brian Taylor (trad.). 3. ed. Porto Alegre: Artmed.

Box, G. E. P., Jenkins, G. M., \& Reinsel, G. C. (2008). Time series analysis: forecasting and control. 4. ed. Hoboken, NJ: John Wiley \& Sons. https://doi. org/10.1002/9781118619193

Bruner, R. F. (2010). Estudos de casos em finanças: gestão para criação de valor corporativo. 5. ed. Porto Alegre: AMGH.

Cerbasi, G. (2008). Investimentos inteligentes: para conquistar e multiplicar o seu primeiro milhão. Rio de Janeiro: Thomas Nelson Brasil.

Cooper, G. (2009). A origem das crises financeiras: bancos centrais, bolhas de crédito e o mito do mercado eficiente. Alfragile: Lua de Papel.

Dezordi, L. L. (2010). Fundamentos de economia. Curitiba: IESDE Brasil S.A.

G1. (2013). Mais de 100 milhöes de brasileiros optam pela caderneta de poupança. São Paulo, 10 mai. 2013. Available at http://g1.globo.com/sao-paulo/ noticia/2013/05/mais-de-100-milhoes-de-brasileirosoptam-pela-caderneta-de-poupanca.html

Gallagher, L. M. (2008). Planeje seu futuro financeiro: o guia sobre investimentos para multiplicar seu patrimônio. Rio de Janeiro: Elsevier.
Hair Jr., J. F., Babin, B., Money A. H. \& Samouel, P. (2003). Fundamentos de métodos de pesquisa em administração. Porto Alegre: Bookman.

Hissa, M. (2012). Eu quero ser rico! Passo a passo para alcançar a independência financeira. Rio de Janeiro: Elsevier.

Modenesi, A. M. (2005). Regimes monetários: teoria e a experiência do real. Barueri: Manole.

Newlands Junior, C. A. (2011). Sistema financeiro e bancário: teoria e questôes. 3. ed. Rio de Janeiro: Elsevier

Paz, L. \& Bastos, M. (2012). Mercados futuros (recurso eletrônico): como vencer operando futuros. Rio de Janeiro: Elsevier.

Posner, R. et al. (2012). Regulação financeira para advogados. Rio de Janeiro: Elsevier.

Roberts, R. (2000). Por dentro das finanças internacionais: guia prático dos mercados e instituiçôes financeiras. Translation by Maria José Cyhlar Monteiro. Rio de Janeiro: Jorge Zahar.

Roncari, L. (2002). Literatura brasileira: dos primeiros cronistas aos últimos românticos. 2. ed. São Paulo: Universidade de São Paulo.

Valente, V. (2012). Cultura luso: brasileira. Curitiba: IESDE.

Fecha de recepción: 19 de setiembre de 2017 Fecha de aceptación: 29 de mayo de 2018 Correspondencia: Iferruz@unizar.es baggiod@unijui.edu.br gabrielacsheffer@hotmail.com brunafaccinflor@hotmail.com 